\title{
PERBEDAAN POLITICAL AWARENESS DILIHAT DARI PERAN GENDER PEMILIH PEMULA
}

\author{
Rojihah, Lusy Asa Akhrani, Nur Hasanah \\ Rojihahjeje@gmail.com \\ Program Studi Psikologi Fakultas Ilmu Sosial dan Ilmu Politik \\ Universitas Brawijaya
}

\begin{abstract}
ABSTRAK
Tuntutan adanya kesetaraan gender dalam bidang politik yang disuarakan oleh gerakan feminis di Indonesia pada akhirnya membuahkan hasil. Pemerintah akhirnya mengeluarkan kebijakan affirmatif action, yaitu memberi kuota $30 \%$ bagi perempuan dalam persaingan politik di Indonesia. Pemuda sebagai pemilih pemula adalah agent of change, moral force, iron stock dan social control yang memiliki kontribusi besar untuk mewujudkan kebangkitan bangsa.Tujuan dari penelitian ini adalah untuk mengetahui apakah ada perbedaan kesadaran politik dilihat dari peran gender pemilih pemula. Desain enelitian ini menggunakan metode kuantitatif komparasi. Teknik pengumpulan data dilakukan dengan menyebarkan skala political awareness serta skala peran gender. Reliabilitas menggunakan formula Cronbach Alpha. Uji asumsi penelitian ini menggunakan uji normalitas dengan formula Kolmogorov Smirnov dan uji homogenitas dengan Levene's test. Uji Hipotesis menggunakan anova satu jalur (one way anova) menggunakan bantuan SPSS 20.0 for widows. Hasil penelitian ini menunjukkan hasil yang tidak signifikan karena $\mathrm{p}>0,05$ yang menunjukkan bahwa political awareness tidak bisa dibedakan berdasarkan peran gender.
\end{abstract}

Kata kunci : political awareness, gender, pemilih pemula

Wacana tentang keterlibatan perempuan dalam politik masih menjadi perdebatan tersendiri di kalangan masyarakat. Namun, jika dilihat dari perkembangannya sendiri, kehadiran perempuan dalam dunia politik bisa dijadikan sebuah indikasi bahwa negara tersebut telah terjadi kemajuan demokrasi. Tuntutan adanya kesetaraan gender dalam bidang politik yang disuarakan oleh gerakan feminis di Indonesia pada akhirnya membuahkan hasil. Menurut Azis (2013) Pemerintah akhirnya mengeluarkan kebijakan affirmatif action, yaitu memberi kuota $30 \%$ bagi perempuan dalam persaingan politik di Indonesia yang termaktub dalam Undang-Undang Pemilu No. 12
Pasal 65 Tahun 2003. Pemuda sebagai pemilih pemula adalah agent of change, moral force, iron stock dan social control yang memiliki kontribusi besar untuk mewujudkan kebangkitan bangsa.

Data Komisi Pemilihan Umum (KPU) menunjukkan, jumlah pemilih pemula pemilu 2014 yang berusia 17 sampai 20 tahun sekitar 14 juta orang. Kesadaran politik merupakan kondisi psikologis yang tanggap terhadap segala hal yang berkaitan dengan kehidupan bernegara. adanya kesadaran politik pada masyarakat memungkinkan mereka untuk menjadi anggota masyarakat yang menurut Almond (1999) berbudaya politik partisipan yakni orang-orang secara aktif melibatkan diri dalam kehidupan politik. 
Menurut Syamsuddin (Dja'far,2008) aktif dalam kehidupan politik tidak perlu diartikan bahwa warga negara harus terjun berpolitik praktis. Setidaknya masyarakat memiliki pengetahuan yang memadai tentang sistem politik sehingga mereka sadar dan memahami kemana mereka akan dibawa. Kesadaran politik dipercaya sebagai modal minimal dalam kehidupan bernegara, dengan memiliki kesadaran politik yang memadai, rakyat bisa menilai dan bereaksi terhadap gejala-gejala politik yang ada disekitarnya baik positif dan negatif. Ruang publik dalam konteks ruang politik yang didominasi laki-laki adalah karena dorongan kebudayaan yang belum berpihak kepada perempuan. Hubungan perempuan dan politik tidak lepas dari image dan konstruksi sosial perempuan dalam relasi masyarakat. Image yang selama ini muncul di benak masyarakat adalah perempuan tidak layak masuk ke dunia politik karena politik itu kejam, keras dan penuh debat, yang hal itu hanya layak dan bisa dipenuhi oleh lakilaki. Sehingga peneliti berasumsi bahwa hal demikian juga dipengaruhi oleh kesadaran politik yang berbeda antara laki-laki maupun perempuan.

Kesadaran politik merupakan kondisi psikologis yang tanggap terhadap segala hal yang berkaitan dengan kehidupan bernegara. adanya kesadaran politik pada masyarakat memungkinkan mereka untuk menjadi anggota masyarakat yang menurut Almond (1990) berbudaya politik partisipan yakni individu-individu secara aktif melibatkan diri dalam kehidupan politik. Pemilih pemula belum mempunyai bekal pengetahuan yang cukup terhadap suatu organiasi yang mengarah dibidang politik berbeda dengan pemilih yang sudah pernah terlibat aktif dalam pemilihan umum. kurangnya sosialisasi politik dari lingkungan sekolah dan masyarakat, kurangnya sosialiasi erta simulasi pemilihan umum yang dilakukan KPU (Komisi Pemilihan Umum) kepada pemilih pemula, sehingga kesadaran politik masih belum maksimal (Tyas \& Harmanto, 2014).

Kesadaran politik secara konsisten dikaitkan dengan pengetahuan individu tentang berbagai isu dan fenomena politik, oleh karena itu setiap kali pengetahuan ini diperkaya, kemampuan untuk lebih memahami masalah politik meningkat, yang disebut kesadaran politik. Perkembangan politik di masyarakat umumnya diukur dengan kesadaran politik yang membantu mengembangkan gerakan demokrasi dan politik negara. sehingga berdasarkan fenomena di atas dilakukan penelitian tentang perbedaan tingkat kesadaran politik antara laki-laki dan perempuan pada pemilih pemula karena pemilih pemula baik laki-laki maupun perempuan merupakan pemilih yang baru pertama kali memiliki hak suara karena faktor usia, yang berdasarkan asumsi penulis pemilih pemula belum begitu mengenal dunia politik serta memiliki kemungkinan menjadi target kampanye politik pada periode ini sehingga penelitian ini diharapkan mampu menjadi salah satu sumber untuk membuat kebijakan yang memiliki nilai untuk mempertimbangkan kesadaran politik pada pemilih pemula dilihat dari gender berdasar perspektif psikologi politik.

\section{METODE}

\section{Partisipan dan Desain Penelitian}

Penelitian ini melibatkan keseluruhan dari Mahasiswa Fakultas Ilmu Sosial dan Ilmu Politik yang termasuk dalam kategori pemilih pemula pada 
pemilu 2014 secara spesifik merupakan angkatan 2011, 2012 dan 2013 sebagai populasi, sedangkan sampel penelitian menggunakan teknik non probability sampling, yaitu dengan purposive sampling. Pemilihan sampel dengan menggunakan teknik purposive dilakukan karena sampel yang terpilih harus memiliki karakteristik-karakteristik khusus sesuai dengan tujuan dari penelitian.

Desain penelitian yang digunakan dalam penelitian ini adalah metode kuantitatif yang bersifat komparasi atau perbedaan, yaitu jenis penelitian yang bertujuan untuk membedakan atau membandingkan hasil penelitian antara dua atau lebih kelompok penelitian.

Penggunaan teknik purposive sampling pada penelitian ini didasarkan pada penilaian terhadap karakteristikkarakteristik yang dimiliki oleh anggota dalam populasi yang dianggap mampu memberikan informasi yang sesuai dengan tujuan penelitian atau menjawab penelitian, karena memiliki karakteristik yaitu, 1) Mahasiswa Fisip Universitas Brawijaya angkatan 2011, 2012 dan 2013, 2) berusia 17-21 tahun pada tahun 2014,3 ) Menghadapi pemilu legislatif maupun pemilu presiden pertama kali tahun 2014 saat penelitian, peneliti memustuskan untuk mengambil sampel sebanyak 125 mahasiswa yang terdiri dari 50 mahasiswa laki-laki dan 75 mahasiswa perempuan.

\section{Instrumen Penelitian}

Metode pengumpulan data dengan skala digunakan untuk mengukur data yang berupa konsep psikologis (Azwar, 2012). Hal tersebut dapat diungkap melalui indikator-indikator untuk kemudian disusun berupa aitem-aitem pertanyaan atau pernyataan. Melalui skala tersebut, atribut-atribut tertentu dapat diungkap melalui respon pertanyaan tersebut.Alat ukur yang digunakan dalam penlitian ini adalah sebanyak dua skala yaitu skala peran gender yang diadaptasi dari penelitian sebelumnya milik Wathani (2009) yang diadaptasi dari skala milik Bem yaitu BSRI ( Bem Scale Role Inventory) meliputi aspek maskulin, feminin dan androgini dengan item sejumlah 29 item. Hasil uji coba skala peran gender menunjukkan bahwa alat ukur valid dan reliabel dengan koefisien reliabilitas sebesar 0,913. Sedangkan alat ukur political awareness disusun sendiri oleh peneliti berdasarkan dimensi menurut Agboola dan Adekeye (Abonu, Agunlade \& Yunusa, 2013) dengan keseluruhan item berjumlah 20 item. Nilai koefisien reliabilitas untuk skala political awareness sebesar 0,847.

Pelaksanaan penelitian dilakukan dengan memberikan skala kepada subjek penelitian, yaitu mahasiswa FISIP Universitas Brawijaya Malang angkatan 2011, 2012 dan 2013 yang sesuai dengan karakteristik subjek penelitian.

\section{Analisis Data}

Analisis data menggunakan one-way ANOVA untuk mengetahui apakah sampel kelompok tersebut sama atau berbeda. Selanjutnya data diolah dengan menggunakan bantuan program SPSS 20.0 for windows.

\section{HASIL}

\section{Uji asumsi}

Skala diberikan kepada subjek dengan jumlah 177 mahasiswa yang sesuai dengan karakteristik subjek penelitian, kemudian diseleksesi hingga tersisa 125 mahasiswa yang memenuhi karakteristik penelitian, 32 mahasiswa sisanya gugur karena tidak memenuhi salah satu 
karakteristik penelitian yaitu belum pernah mengikuti pemilu legislatif pada tahun 2014.

Uji asumsi terdiri dari uji normalitas dan uji homogenitas. Uji normalitas meliputi persebaran data pada satu variabel yaitu, variabel bebas (political awareness). Selanjutnya juga dilakukan uji homogenitas untuk mengetahui apakah populasi dan sampel yang digunakan dalam penelitian adalah homogen (sejenis) atau tidak. Uji normalitas dan uji homogenitas pada penelitian ini dilakukan dengan bantuan SPSS (Statistical Package for Social Science) version 20.0 for windows.

\section{Uji Normalitas}

Uji normalitas dilakukan untuk mengetahui apakah populasi data terdistribusi secara normal atau tidak. Uji normalitas dalam penelitian ini akan dianalasis menggunakan tes KolmogorovSminov dengan bantuan SPSS (Statistical Package for Social Science) version 20.0 for windows dengan tingkat signifikansi 0,05. Populasi data dikatakan terdistribusi secara normal apabila hasil tes Kolmogorov-Sminov(p)> 0,05. berikut ini adalah hasil uji normalitas KolmogorovSminovdengan bantuan SPSS (Statistical Package for Social Science) version 20.0 for windows. Hasil uji noormalitas dengan tes Kolmogorov-Smirnov pada masingmasing variabel dapat dilihat pada tabel 1 dibawah ini.
Tabel 1

Hasil Uji Normalitas

\begin{tabular}{cccc}
\hline Variabel & Hasil & Sig. & Ket. \\
\hline Political & 1,073 & 0,200 & Nor \\
Awareness & & & mal \\
\hline
\end{tabular}

Berdasarkan tabel 1 menunjukkan hasil dari uji Kolmogorov-Smirnovpada variabel political awareness menunjukkan angka 1,073 dengan nilai signifikansi 0,200 yang berarti $(p)>0,05(0,200>0,05)$ maka populasi data dikatakan terdistribusi normal.

\section{Uji Homogenitas}

Uji homogenitas diperlukan untuk mengetahui apakah populasi dan sampel yang digunakan dalam penelitian adalah homogen (sejenis) atau tidak. Uji homogenitas dilakukan dengan menggunakan Levene's Test, alasan menggunakan metode Levene's test karena penelitian ini hanya membandingkan dua varians. Data dikatakan homogen jika signifikansi yang diperoleh $>0,05$. Hasil uji linieritas dapat dilihat pada tabel 2 berikut ini.

Tabel 2

Hasil Uji Homogenitas

\begin{tabular}{cccc}
\hline Variabel & Hasil & Sig. & Ket. \\
\hline Political & 0,922 & 0,433 & Homogen \\
Awareness & & & \\
\hline
\end{tabular}

Berdasarkan tabel 2 dapat disimpulkan bahwa pada variabel dependen (political awareness) hasil Levene's testsebesar 0,922dan nilai signifikansi sebesar 0,433 sehingga data dikatakan homogen (sejenis) karena $0,433>0,05$. 


\section{Hasil Uji Hipotesis}

Uji hipotesis pada penelitian ini adalah menguji perbedaan political awareness dilihat dari peran gender pemilih pemula dengan menggunakan uji one way anova (anova satu jalur) dilanjutkan dengan post-hoc test (menguji tiap dua kelompok) dengan bantuan SPSS (Statistical Package for Social Science) version 20.0 for windows.

Selanjutnya uji one way anova menunjukkan hasil sebagai berikut:

Tabel 3

Hasil uji one way anova

\begin{tabular}{ccccccc}
\hline & $\begin{array}{c}\text { Sum } \\
\text { of } \\
\end{array}$ & & & & & \\
& Squ \\
ares & Df & Mean & Square & $F$ & Sig.. & Ket \\
& & & & & \\
\hline Between & 68,4 & 3 & 22.800 & 0,8 & 0,47 & Tid \\
Groups & 01 & & & & & ak \\
& & & & & & sig \\
& & & & & & nifi \\
& & & & & & kan \\
& & & & & & \\
Within & 328 & 121 & 27,164 & 39 & 5 & \\
Groups & 6,79 & & & & & \\
& 9 & & & & & \\
\hline
\end{tabular}

Berdasarkan tabel 3 menunjukkan hasil uji one way anova pada variabel dependen (political awareness). Sum of squares atau jumlah kuadrat dari deviasi masing-masing pengamatan menunjukkan nilai 68,401 untuk variansi antar kelompok sedangkan nilai 3286,799 untuk variansi dalam kelompok. derajat kebebasan antar kelompok berjumlah tiga sedangkan derajat kebebasan dalam kelompok berjumlah 21. Mean square atau rata-rata kuadrat antar kelompok menunjukkan nilai 22,800 sedangkan rata-rata kuadrat dalam kelompok menunjukkan nilai 27,164. F empiris pada penelitian ini bernilai 0,839 dan Signifikansi pada uji one way anova ini menunjukkan nilai 0,475 yang berarti hasil dari uji one way anova ini tidak signifikan karena sig > 0,05 yaitu $(0,475>$ 0,05). Sehingga bisa ditarik kesimpulan bahwa hipotesaa alternatif dari penelitian ini ditolak sedangkan hipotesaa awal diterima (Ha ditolak, H0 diterima). Peneliti selanjutnya mencoba menggunakan Multiple comparison melalui post hoc test dependen variabel (political awreness) dan menunjukkan hasil sebagai berikut

Tabel 4

Hasil Post Hoc Tests

\begin{tabular}{ccccc}
\hline $\begin{array}{c}\text { (I) Peran } \\
\text { gender- } \\
\text { (J) Peran } \\
\text { gender }\end{array}$ & $\begin{array}{c}\text { Perbedaan } \\
\text { rata-rata } \\
\text { (I-J) }\end{array}$ & $\begin{array}{c}\text { Standar } \\
\text { Error }\end{array}$ & Sig. & Ket. \\
\hline Feminin- & 0,328 & 1,655 & 0,84 & Tid \\
Maskulin & & & 3 & ak \\
& & & & sign \\
& & & & ifik \\
& & & & an \\
\hline
\end{tabular}

Tabel 4 menunjukkan hasil pengujian terhadap dua kelompok penelitian. Perbedaan rata-rata antara peran gender feminin dibandingkan dengan peran gender maskulin bernilai 0,328, standar error menunjukkan nilai 1,655 dan nilai signifikansi sama-sama menunjukkan nilai 0,843 yang berarti sig > 0,05 yaitu $(0,843>0,005)$ maka hasilnya tidak signifikan atau H0 diterima sedangkan Ha ditolak. Kesimpulan dari masing-masing uji hipotesa yang dilakukan baik uji one way anova maupun post hoc tests sama-sama menunjukkan bahwa hasil penelitian ini tidak signifikan karena sig > 0,05 yang berarti hipotesa awal penelitian diterima sedangkan hipotesa alternatif dari peneliti ditolah $\mathrm{H} 0$ diterima Ha ditolak, berarti variabel dependen berupa political awarenss tidak dapat dibedakan menurut peran gender. 


\section{DISKUSI}

Penelitian ini melibatkan 125 mahasiswa yang terdiri dari 55 orang mahasiswa dan 70 mahasiswi sebagai sampel penelitian, berdasarkan skala peran gender yang diberikan didapatkan hasil peran gender maskulin sebanyak 14 orang, feminin sebanyak 34 orang, androgini sebanyak 33 orang dan undifferentiated sebanyak 44 orang. Syarat diterimanya hipotesa adalah ketika nilai sig $<0,005$ sedangkan pada penelitian ini sig >0,05 yaitu pada uji one way anova yang menunjukkan 0,475 > 0,05 sehingga hasil yang diperoleh dikatakan tidak signifikan, begitu pula ketika di uji melalui post hoc tests menunjukkan nilai $0,485>0,05$ sehingga dapat dapat ditarik kesimpulan melalui uji one way anova maupun post hoc test hasil data penelitian ini dikatakan tidak signifikan yang berarti political awareness tidak dapat dibedakan menurut peran gender seseorang. Surbakti (2010) menyatakan bahwa kesadaran politik adalah kesadaran akan hak dan kewajiban sebagai warga negara, hal ini menyangkut pengetahuan seseorang tentang lingkungan masyarakat dan politik dan menyangkut minat dan perhatian seseorang terhadap lingkungan masyarakat dan politik tempat ia hidup. Graber (Ibagere, 2013) mengungkapkan bahwa kesadaran politik adalah mempelajari, menerima serta mengakui kebiasaan, aturan, struktur dan faktor lingkungan kehidupan politik pemerintahan.

Seorang warga negara yang memiliki kesadaran politik akan sadar untuk memberikan hak suaranya di dalam pemilu, memantau kebijakan yang dikeluarkan pemerintah dan mengajukan kritik terhadap pemerintah manakala ia melihat pemerintah tidak memberikan hakhak yang seharusnya ia dapat sebagai seorang warga negara. International Journal of Education and Research vol. 1 no. 12 tahun 2013 yang berjudul Assesment of Political Awareness Among Students of Social Studies in Nigerian Secondary School for citizenship oleh Abonu, Ogundale \& Yunusa membahas tentang investigasi dari enam area geopolitik di Nigeria melibatkan pelajar JSSIII sebagai subjek. Alat ukur yang digunakan yaitu cognitive aspect of political awareness in social study education (CAPASSE), effective aspect of political awareness in social study education (AAPASSE) dan terakhir psychomotor aspect of political awareness in social study education (PAPASSE). Hasil dari penelitian ini menggunakan one way analysis of variance ditemukan bahwa tidak ada indikasi perbedaan signifikan antara hasil dari CAPASSE, AAPASSE dan PAPASSE. Peneliti berasumsi bahwa ada beberapa faktor yang mempengaruhi munculnya suatu kesadaran politik seorang individu, seperti umur, jenis kelamin, dan status pendidikan sehingga dijadikan sebagai data demografis dalam skala penelitian. Hasil penelitian menemukan bahwa tingkat pendidikan dan serta mudahnya akses komunikasi yang menentukan ada atau tidaknya perbedaan peran gender terhadap political awareness, subjek pada penelitian ini terdiri dari mahasiswa yang sama-sama menempuh pendidikan Strata satu di Fakultas Ilmu Sosial dan Ilmu Politik Universitas Brawijaya meskipun mereka subjek terbagi-bagi dalam berbagai macam jurusan yaitu ilmu komunikasi, sosiologi, psikologi, hubungan internasional, ilmu politik dan ilmu pemerintahanan. Selain itu mudahnya akses informasi dan komunikasi juga memiliki peran yang besar terhadap penerimaan pengetahuan 
mengenai politik karena pada tahun pertama perkuliahan semu jurusan dan program studi di Fakultas Ilmu Sosial dan Ilmu Politik memberikan mata kuliah pengantar ilmu politik, sehingga kedua faktor tersebut yang menurut asumsi peneliti menjadi penyebab tidak adanya perbedaan political awareness pada penelitian ini.

Penelitian selanjutnya diharapkan dapat melibatkan subjek dengan karakteristik yang berbeda misalnya, mahasiswa yang lebih beragam tidak hanya dari Fakultas Ilm Sosial dan Ilmu Politik, tetapi juga dari fakults eksakta misalnya Kedokteran, Pertanian, Perikanan dan lain sebagainya. Subjek yang beraneka ragam nantinya diharapkan dapat merepresentasikan mengenai political awareness yang beragam pula.

\section{KESIMPULAN}

1. Penelitian ini menunjukkan bahwa tidak ada perbedaan political awareness antara peran gender maskulin dan peran gender feminin berdasarkan hasil analisis menunjukkan $(p>0,05)$ yaitu $(0,475>0,05)$.

2. Analisis tambahan dari penelitian ini, peneliti juga melihat perbandingan antara tipe peran gender lainnya yaitu androgini dan undifferentiated dan didapatkan hasil yang tidak berbeda dengan perbandingan tipe peran gender lainnya, yaitu tidak ada perbedaan signifikan, sehingga dapat ditarik kesimpulan bahwa political awareness tidak dapat dibedakan menurut peran gender.

\section{DAFTAR PUSTAKA}

Almond, A.Gabriel, Verba S. (1990). Budaya Politik, Tingkah Laku Politik dan Demokrasi di Lima Negara. Bumi Aksara: Jakarta.

Azis, A. (2013). Dilema Keterwakilan Perempuan dalam Parlemen. Yogyakarta: Rangkang Education.

Azwar, S. (2012).Penyusunan Skala Psikologi. Yogyakarta: Pustaka Pelajar.

Baron, Robert A \& Byrne, Donn. (2004).Psikologi Sosial. Jakarta: Erlangga.

D. N. Abonu., F.O Agunlade \& B.M Yunusa. (2013). Assesment of Political Awareness Among Students of Social Studies in Nigerian Secondary Schools for Citizenship. International Journal of education research, 1, p1-10.

Dja'far, Y. (2008). Peranan Pers dalam Meningkatkan Kesadaran Politik Masyarakat. Jurnal ilmiah Dinamika, 1, hal1-4.

Ibagere, E. (2013). The Mass Media, Nigerian's Political Awareness and Their Capacity to Make Political Choices. European Journal of Arts and Humanities. 1(2), p68-78.

Poerwanti, E. (2000). Pendekatan Kuantitatif dalam Penelitian Perilaku. Malang: Universitas Muhammadiyah Malang.

Surbakti, R. (2010). Memahami Ilmu Politik. Jakarta: PT. Grasindo.

Tyas, F.S \& Harmanto. (2014). Peran Orang Tua dalam Menanamkan 
Perbedaan Political Awareness Dilihat dari Peran Gender Pemilih Pemula

Kesadaran Politik pada Anaknya sebaga Pemilih Pemula di Kelurahan Tambakrejo Kecamatan Simokerto Surabaya. Jurnal Kajian Moral dan Kewarganegaraan, 1, hal 273-289

Wathani, F. (2009). Perbedaan Kecenderungan Pembelian Impulsif Produk Pakaian Ditinjau dari Peran Gender. Skripsi Universitas Sumatera Utara. Tidak ditebitkan. 